\title{
BULIMIA NERVOSA BETWEEN ISLAMIC LAW AND HEALTH PERSPECTIVE
}

\author{
Oleh: Suhartina Rustam¹, Muhammad Sabir, Abdul Rahman Qayyum \\ ${ }^{1}$ E-mail : rustamsuhartina@gmail.com \\ Fakultas Syariah dan Hukum UIN Alauddin Makassar
}

\begin{abstract}
The purpose of this research is to 1) determine the factors that influence the employees of Bank Axa Mandiri Makassar City to carry out Bulimia Nervosa. 2) To formulate the prevention and treatment of bulimia nervosa. 3) To indetify the harm of bulimia nervosa behavior in terms of health and Islamic law aspects. Answering these problems, the author uses the health and syar'i approach. The health approach is used because it refers to the scope of Islamic law. This type of research is qualitative research (field research), then a sociological (community) approach technique by examining the field's facts. This study's results indicate the factors that cause the employees of the Makassar City Axa Mandiri Bank to commit Bulimia nervosa, namely because of the demands of their work and wanting to satisfy their appetite. In terms of health aspects, the harmful behavior of bulimia nervosa can cause various diseases. As for the behavior of bulimia nervosa in terms of Islamic law, it is an act that is prohibited and makes the perpetrator will get a sin. Bulimia nervosa prevention can be done with gratitude, increased self-confidence, being realistic, adjusting eating patterns, and socializing. Several steps can be taken to take action to treat bulimia nervosa with psychologist therapy.
\end{abstract}

Keywords : Bulimia Nervosa; Health; Islamic Law

\section{INTRODUCTION}

Food intake that is consumed must be considered properly because food is very important and has a big influence on humans' survival. Religion strongly recommends paying attention to the intake of food to be consumed, because the food that enters the body has a major influence on the development of human thought patterns and morals. The recommendations for paying attention to food are as in the word of Allah SWT in Surah' abasa / 80: 24, which discusses how important it is to pay attention to food.

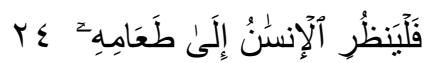

Meaning: Let people then consider their food.

The suggestion to pay attention to food has been clearly explained in the above verse. Religion recommends that we pay attention to the intake of food that we will consume because healthy food has health benefits for the body while unhealthy food 
will cause various diseases to the human body. ${ }^{1}$ In the modern era, humans are increasingly prosperous and happy to enjoy the unlimited luxury of a world, but behind this, sometimes some behaviors can cause harm without us knowing it due to the mistakes ourselves.

Behavior that can cause harm to oneself is bad and must be avoided. One example of bad behavior that occurs in the aspect of the diet is dietary irregularities. Diverting eating patterns is a behavior where a person violates eating rules that are not following a healthy diet. ${ }^{2}$ A healthy diet is a method or effort to regulate the amount, type of food, according to the recommendation of a healthy diet according to a health perspective and a religious perspective that refers to the Prophet's healthy diet. $^{3}$

Dietary patterns have recently occurred and generally often affect women. Lifestyle transition, social assessment in order to look beautiful are some of the triggers for dietary irregularities. The public's perception that a beautiful woman has an ideal body with indicators of a thin and lingering body causes women to be willing to go on a strict diet and deviate dietary behavior to get the body shape they desire.

According to the Diagnostic and Statistical Manual of Mental Disorders, three types of eating disorders are classified as Anorexia Nervosa, Bine-Eating, and Bulinia Nervosa. ${ }^{4}$ Anorexia nervosa is an eating disorder by making him feel hungry to make him hungry to look slim and make the opposite sex the most attractive. In contrast to anorexia nervosa, eating disorder bulimia nervosa is a condition in which a person consumes an excessive amount of food, then the food is forcibly removed using certain methods. ${ }^{5}$

Bulimia nervosa or forcible removal of food using certain methods makes the food consumed does not have time to be absorbed by the human body. Food expenditure in bulimia nervosa behavior is divided into two types, namely: purging type and non-purging type. Purging type is the expenditure of food using drugs, but this behavior will cause negative implications, namely various diseases will attack the human body.

According to the National Institute of Mental Health, cases of bulimia nervosa are generally experienced by women than men because women pay more attention to their body shape than men. This is due to social perceptions that assume that a beautiful woman is a woman who has an ideal body shape with the characteristics of a thin and lanky body then the influence of social media and magazines so that it

\footnotetext{
1 Al-Asyhar, Thobieb, Bahaya Makanan Haram Bagi Kesehatan Jasmani dan Kesucian Rohani, (Jakarta: Al: Mawardi Prima, 2003), h. 112

2 Proverawati, Atikah. Obesitas dan Gangguan Perilaku Makan Pada Remaja, Yogyakarta: Nuha Medika, 2010. H. 79

3 Sumantri, Arief. Mengikuti Pola Makan sehat Dunia Kesehatan dan Sunah Nabi, Jakarta: Salemba Medika. 2012. H. 76

${ }^{4}$ Hetty, Krisnai, dkk. "Gangguan Makan Anorexia Nervosa dan Bulinia Nervosa pada Remaja" Prospedin Penelitian dan Pengabdian Kepada Masyarakat,, vol. 4 no. 3 (Desember 2017) h. 399 jurnal.unpad.ac.id (Diakses 03 Maret 2020).

5 Hetty, Krisnai, dkk. "Gangguan Makan Anorexia Nervosa dan Bulinia Nervosa pada Remaja," h. $400-401$
} 
affects the mindset and triggers women's actions to carry out various diet programs and methods. A special method to have the ideal body shape.

Various studies on bulimia nervosa have been widely conducted and show results that cannot be considered normal. Based on a longitudinal study conducted by Mc Knight in 2003, in Arizona and California, it was found that 32 young women (29\%) experienced bulimia nervosa. A study in ANRED in 2005 showed that about $1 \%$ of adolescent girls suffer from anorexia nervosa, meaning that about one in every hundred teenage girls between 10 and 20 starve themselves sometimes to death. About $4 \%$ of adolescent girls deliberately vomit their food, and about $50 \%$ of adolescents with anorexia nervosa develop bulimia nervosa.

A study in the United States in 1996 conducted by Berk stated that bulimia nervosa was more common than anorexia nervosa, where about $2-3 \%$ of teenage girls experienced bulimia nervosa. The research conducted in Indonesia, including research conducted by Hapsari in 2009 among models at the QQ Modeling School, South Jakarta, stated that $58.5 \%$ tended to have eating disorders with anorexia nervosa specifications as much as $3.1 \%$, bulimia nervosa as much as $1.5 \%$.

In the city of Makassar, cases of bulimia nervosa are rarely published. This is because the public is still taboo about it. However, this behavior harms the perpetrators. Therefore, researchers are interested in raising bulimia nervosa to be the object of this study by synchronizing the aspects of health and Islamic law with the research title "Analysis of Bulimia Nervosa Behavior Analysis in terms of Health and Islamic Law Aspects (Case Study of Bank Axa Mandiri Bank Employees, Makassar City)."

Based on the background of the problem, then the problem is formulated that will be the basis for preparing this thesis, namely 1) What factors influence the employees of Bank Axa Mandiri Makassar City to carry out Bulimia Nervosa? 2) How is the harmful behavior of bulimia nervosa reviewed from the aspects of health and Islamic law? 3) How to prevent and treat bulimia nervosa? This study's objectives are as follows 1) To determine the factors that influence the employees of Bank Axa Mandiri Makassar City to carry out Bulinia Nervosa. 2) To know the prevention and treatment of bulimia nervosa 3) To know the harm of bulimia nervosa behavior from the aspects of health and Islamic law.

So the operational definition that needs to be explained by yaitun bulimia nervosa is a dietary irregularity, utilizing a person eating in an abnormal portion. The food is forcibly removed because he does not want to experience weight gain, regarding the factors that cause Bank Axa Mandiri Makassar City employees to commit bulimia nervosa. Regarding harm, it is anything that can cause negative impacts in the form of loss and badness, misery, and disease-both in terms of health and Islamic law.

This study uses a health and syar'i approach. The health approach is used because it refers to the scope of Islamic law. This type of research is qualitative research (field research), so the sociological (community) approach technique is to study the field's facts. 


\section{Literature Review}

Bulimia nervosa was first formally introduced by Rusell in 1979. Rusell said that bulimia consists of three factors: episodes of eating large amounts, avoiding the effects of obesity from food by vomiting or using laxatives, and fear of becoming fat. 6 According to Santrock: bulimia nervosa is an eating disorder in individuals who consistently follow a pattern, overeat and regurgitate. ${ }^{7}$ According to Janet: bulimia nervosa is an eating disorder characterized by episodes of overeating or large amounts of food and vomiting.

According to Davidson, the word bulimia comes from Latin, which means cow or buffalo, and limos which means hungry. Bulimia is characterized as a state of overeating (binge) consisting of the uncontrolled and uncontrolled consumption of a high-calorie amount of food. ${ }^{8}$ Based on several opinions, it can be concluded that bulimia nervosa behavior is a dietary disorder where a person consumes an excessive amount of food. Then the food is forcibly removed using certain methods because of the unwillingness to experience weight gain.

In the view of Islam, a healthy diet is a form or way of consuming food following religious rules, which follow the dietary habits of the Prophet Muhammad. Rasulullah saw himself as a role model for humanity, not only regarding morals and worship but on a healthy diet and eating ethics that we should follow and apply. Following the Prophet Muhammad's diet is a good guideline for all of us Muslims because following the Prophet Muhammad can bring benefits to the body.

Regarding the manners and ethics applied by the Prophet Muhammad, it turns out to have a close relationship with health. One example is the Prophet Muhammad saw forbidding his people to eat and drink standing chili sauce, which is medically proven by modern medical science which reveals that drinking while standing causes water to fall hard on the bottom of the stomach and pound it so that the stomach is loose and digestion becomes difficult.

\section{METHOD}

The data in this study are divided into two, namely primary data and secondary data. Primary data in this study were obtained through direct observation and interviews with the subject of bulimia nervosa, as for the secondary data in this study in the form of books, journals, and several articles related to the object of the problem under study.

\section{RESULT \& DISCUSSION}

Data analysis was carried out during field data collection, and after all, data was collected using interactive model analysis techniques. As data analysis takes place together with the data collection process with the following stages, namely 1) Reduction, the data obtained is written in a detailed report or data. Reports

${ }^{6}$ Cynthia L, Ogden, Prevalence Of High Body Mass Index in children and Adolescents (Jama, 2007) h. 303

7 Jhon W, Shantrock, Life Span Development (USA, Mc Grow Hill,1999) h. 102

8 Naela G.C, Davidson \& Kring A.M, Psikologi Abnormal (Jakarta, PT Raja Grafindo Persada, 2006) h. 9 
compiled based on the data obtained are reduced, summarized, main things are selected, focused on important things. 2) Data Presentation, the data obtained are categorized according to the subject matter and made in the form of a matrix, making it easier for researchers to see patterns of relationships between one data and another. 3) Conclusion and Verification. Each initial conclusion is still a temporary conclusion that will change if new data is obtained in the next data collection. Data conclusions obtained while in the field were verified during the study by rethinking and reviewing field notes to form conclusions. It is hoped that this conclusion can be obtained after the data collection is complete. ${ }^{9}$

Based on interviews with researchers with Bulimia Nervosa sufferers or perpetrators who work as Service Customer for Bank Axa Mandiri in Makassar City, several factors behind him do this, including 1) Job demands, as a Bank employee who demands him to look beautiful and fashionable. Make himself have to maintain body weight in order to stay ideal. In the office where he works, HRD emphasizes that he looks perfect because he will serve customers. 2) He will satisfy his appetite, the demands of work with a fairly tight schedule. It is starting from getting up early without having time to have breakfast at home and going to the office, arriving at the office starting to serve customers from morning to evening, plus some data that must be cleared up first and meeting Making himself unable to eat and enjoy it. So in a week, he can eat the food he likes and enjoy doing and then vomits back because he doesn't want to get fat.

In terms of health aspects, the harmful behavior of bulimia nervosa can cause various diseases such as tooth decay, feeling tired and tired, swollen salivary glands, and other diseases. As for the behavior of bulimia nervosa in terms of Islamic law, it is an act that is prohibited and makes the perpetrator will get a sin.

Bulimia nervosa behavior is a form of Isrāf's actions in eating and drinking, where a person consumes food excessively, exceeding the amount determined and needed by the body. Isrāf's actions in terms of eating and drinking are hated by Allah Almighty and forbidden to do because they will harm the perpetrator.

When viewed in the present context, those who apply this isräf behavior are nothing but to follow trends or boast with the intent and purpose of showing off what it has. If all he has is fulfilled, this can result in an attitude of arrogance or pride.

The following is the hadīs-ḥadīs that the author found in the hadīs book al-Mu jam al-Mufahras dictionary related to the discussion of isrāf behavior.

Hadis narrated by Aḥmad ibn Hanbal in his book Musnad.

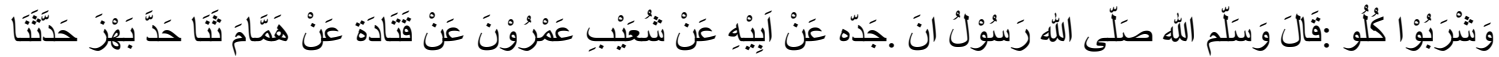

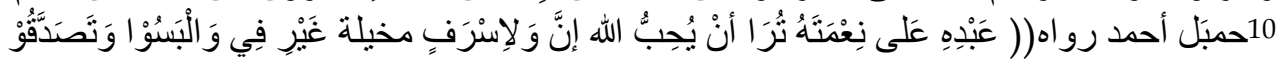

Meaning::

"Bahz told us, Hammam told us, from Qatada, from Amru bin Syu'aib, from his father, from his grandfather, that the Messenger of Allah said, "Eat, drink, give 
alms, and dress, without being arrogant and extravagant. Allah loves to be shown His blessings to his servants". 11

If we analyze bulimia nervosa behavior, it is an action that belongs to the category of wrongdoing. The tyranny on bulimia nervosa behavior is the impact caused by bulimia behavior. The wrongdoing, in this case, is in the form of efforts made by people with bulimia to consume food without having to do zeal or dzolim in Islam is despicable behavior that does not place something or something in its place according to the provisions of Islamic law. the opposite of this dzalim attitude is fair.

Bulimia nervosa prevention can be done by being grateful, increasing selfconfidence, being realistic, adjusting eating patterns, and socializing. Several steps can be taken to take action to treat bulimia nervosa, namely psychological therapy.

\section{CONCLUSION}

Based on the discussion results in this study, the researchers can conclude, namely: 1) Bulimia nervosa is a condition in which a person consumes an excessive amount of food, then the food is forcibly removed using certain methods. 2) The factors that caused Bank Axa Mandiri's employees in Makassar City to do Bulimia nervosa, namely because of the demands of their work and wanting to satisfy their appetite. 3) Harmful behavior of bulimia nervosa in terms of aspects, which can cause feelings of fatigue and fatigue, tooth decay, swelling of the salivary glands, osteoporosis, Arithmetic, menstrual disorders, chronic constipation, emotional disorders, mental disorders, disorders of the esophagus, gastric disease, and disorders. Digestive system. As for the behavior of bulimia nervosa in terms of Islamic law, it is an act that is prohibited and makes the perpetrator will get a sin. Bulimia nervosa prevention can be done with gratitude, increased self-confidence, being realistic, adjusting eating patterns, and socializing. Several steps can be taken to take action to treat bulimia nervosa with psychologist therapy.

\section{BIBLIOGRAPHY}

Al-Qazwini, Abi Abdillah Muhammad bin Yazid, Sunan Ibnu Majah juz 2, darul afkar,:tt

Arief , Sumantri, Mengikuti Pola Makan sehat Dunia Kesehatan dan Sunah Nabi, Jakarta: Salemba Medika. 2012.

Atikah, Proverawati, Obesitas dan Gangguan Perilaku Makan Pada Remaja, Yogyakarta: Nuha Medika, 2010.

Davidson, Naela G.C, \& Kring A.M, Psikologi Abnormal.Jakarta, PT Raja Grafindo Persada, 2006.

Hasman, Ade, Rahasia Kesehatan Rasulullah : Meneladani Gaya Sehat Nabi Muhammad saw., Jakarta Selatan: Naura Books, 2012

Ogden, Cynthia L, Prevalence Of High Body Mass Index in children and Adolescents. Jama, 2007

Shamrock, Jhon W, Life Span Development USA, Mc Grow Hill,1999.

11Ibid h.356 
Sujarweni, Wiratna, Metodologi Penelitian. Yogyakarta: Pustaka Baru Press, 2004.

Thobieb, Al-Asyhar, Bahaya Makanan Haram Bagi Kesehatan Jasmani dan Kesucian Rohani, Jakarta: Al: Mawardi Prima, 2003

Krisnai, Hetty dkk. Gangguan Makan Anorexia Nervosa dan Bulinia Nervosa pada Remaja. vol. 4 no. 3 Desember 2017. 